\title{
Kajian Penentuan Nilai Epsilon Optimal Pada Algoritma DMDBSCAN Dan Pemetaan Daerah Rawan Gempa Bumi Di Indonesia Tahun 2014-2020
}

\author{
(The Study Of Determining Optimal Epsilon Value On The Dmdbscan Algorithm And Mapping \\ Earthquake Proposed Area In Indonesia 2014-2020)
}

\author{
Kamilia Wafa Pakuani ${ }^{1}$, Robert Kurniawan ${ }^{2}$ \\ ${ }^{1,2}$ Politeknik Statistika STIS \\ Jl. Otto Iskandar Dinata No. 64C Jakarta 13330 \\ E-mail: 221709773@stis.ac.id ${ }^{1}$, robertk@stis.ac.id ${ }^{2}$
}

\begin{abstract}
ABSTRAK
Area pengawasan gempa bumi dapat dilakukan dengan menemukan penyebaran poin gempa atau pengelompokan gempa acak. Density-Based Spatial Clustering of Applications with Noise (DBSCAN) adalah salah satu algoritma clustering yang disegel dari sejumlah data besar yang mengandung noise atau outlier. Penelitian sebelumnya mengubah Algoritma DBSCAN untuk secara otomatis menemukan nilai Epsilon (Eps) optimal dengan menggunakan metode Algoritma Dynamic Method DBSCAN (DMDBSCAN). Nilai parameter Eps diperoleh dari perhitungan perubahan slope atau kemiringan garis maksimum pada 3 jarak dari tetangga paling dekat dalam distribusi data. Namun, cara ini rentan terhadap perubahan kemiringan garis yang sangat jauh. Maka dari itu, penelitian ini melakukan modifikasi cara tersebut dengan mencari nilai minimal pada rentang slope antara 10\% hingga 20\%. Nilai Eps yang dihasilkan setelah modifikasi menunjukkan angka yang lebih baik. Oleh karena itu, cara ini diharapkan dapat menjadi referensi untuk pencarian parameter Eps dalam Algoritma DMDBSCAN yang lebih cocok dan mengetahui distribusi titik gempa di Indonesia.
\end{abstract}

Kata kunci: DBSCAN, DMDBSCAN, $k$-dist plot, gempa bumi

\begin{abstract}
Earthquake surveillance areas can be done by finding the distribution of earthquake points or random earthquake groupings. Density-Based Spatial Clustering of Applications with Noise (DBSCAN) is one of the sealed clustering algorithms from large amounts of data containing noise or outliers. Previous research changed the DBSCAN Algorithm to automatically find the optimal Epsilon (Eps) value by using the DBSCAN Dynamic Method Algorithm (DMDBSCAN) method. The value of the Eps parameter is obtained from the calculation of the change in slope or the maximum line slope at 3 distances from the closest neighbor in the data distribution. However, this method is prone to very large changes in the slope of the line. Therefore, this study modified the method by finding the minimum value in the slope range between $10 \%$ to 20\%. The resulting Eps value after modification shows a better number. Therefore, this method is expected to be a reference for finding the Eps parameter in the DMDBSCAN Algorithm which is more suitable and knowing the distribution of earthquake points in Indonesia.
\end{abstract}

Keywords: DBSCAN, DMDBSCAN, k-dist plot, earthquake

\section{PENDAHULUAN}

Wilayah Indonesia terletak pada pertemuan lempeng tektonik. Secara geografis, Indonesia terletak di seberang Cincin Api Pasifik dan sabuk pegunungan tinggi. Kedua hal tersebut menjadikan Indonesia rawan terhadap bencana alam, terutama letusan gunung berapi dan gempa. (Husein, 2016).

Gempa adalah kejadian alam yang bisa terjadi kapan saja serta tidak dapat diprediksi. Besarnya gempa bumi berkisar dari gempa bumi yang sangat kuat yang dapat menyebabkan kerusakan harta benda dan korban jiwa hingga gempa bumi yang sangat kecil yang hampir tidak dapat dirasakan. Kejadian gempa terjadi di sebagian besar dunia, salah satunya adalah Indonesia. Indonesia menjadi satu dari beberapa negara yang memiliki peringkat aktivitas kegempaan yang tinggi, karena Indonesia memiliki letak geografis pada perpotongan tiga lempeng besar di bumi, yaitu: lempeng Pasifik, lempeng Indo-Australia, dan lempeng Eurasia. Lempeng Indo-Australia dan Lempeng Eurasia bertabrakan di selatan Jawa, lepas pantai barat Sumatera dan selatan kepulauan Nusa Tenggara, kemudian membelok ke bagian utara ke arah perairan selatan Maluku. Pada saat yang sama, lempeng Australia dan Pasifik bertabrakan di dekat New Guinea. Akibat tumbukan atau gerak lempeng, pertemuan antar lempeng tersebut dapat menyebabkan seringnya terjadi gempa bumi. Sehingga, Indonesia disebut sebagai wilayah struktural yang rentan gempa (Amri, et al., 2016). 
Menurut data yang diperoleh dari Badan Meteorologi, Klimatologi, dan Geofisika (BMKG), kejadian gempa terjadi setiap hari di wilayah Indonesia, tetapi tidak semua orang bisa merasakan gempa dikarenakan berkekuatan kecil dan titik pusat gempa terletak berjauhan dengan kediaman penduduk. Aktivitas seismik di wilayah Indonesia sering sekali terjadi, dengan rata-rata 400 gempa per bulan. Antara tahun 1991 dan 2007, tercatat 24 gempa bumi besar, termasuk gempa Aceh berkekuatan 9,3 SR yang terjadi pada 26 Desember 2004. Tsunami besar menyusul gempa tersebut, menyebabkan ratusan ribu nyawa dan miliaran rupiah harta benda. dan gempa bumi di Yogyakarta pada 26 Mei 2006 menyebabkan kerusakan parah pada infrastruktur. Gempa di Badong pada 30 September 2009, dengan kekuatan 7,9 skala Richter (SR), menyebabkan kerusakan Rp 4,8 triliun, 1.195 kematian, dan total kerusakan 271.540 rumah. Gempa bumi dan tsunami Aceh 2004 menewaskan hampir 300.000 orang di Indonesia, Thailand, India, Sri Lanka, Maladewa dan Afrika (Sunarjo, Gunawan, \& Pribadi, 2012).

Gempa bumi adalah bencana alam yang tak terhindarkan, tetapi dapat dimitigasi. Data gempa yang didapatkan melalui situs resmi BMKG dapat dipartisi menjadi beberapa kelompok untuk dilakukan pemetaan daerah gempa. Pengelompokkan tersebut diterapkan dengan memanfaatkan metode clustering.

Clustering (pengelompokkan) merupakan proses mempartisi suatu kumpulan titik data ke dalam kelompok-kelompok sehingga nantinya objek-objek pada kelompok yang sama memiliki persamaan yang banyak dan memiliki objek-objek yang berbeda dalam kelompok lainnya. Persamaan dan perbedaan tersebut umumnya didasarkan pada nilai atribut objek-objek tersebut dan bisa pula merupakan perhitungan jarak (Han, Kamber, \& Pei, 2012). Density-Based Spatial Clustering of Applications with Noise (DBSCAN) adalah satu dari beberapa metode pengelompokan berdasarkan kepadatan dan cocok diterapkan pada data yang besar dan memiliki noise atau outlier (Ester, Kriegel, Sander, \& Xu, 1996).

(Rahmah \& Sitanggang, 2016) telah memodifikasi Algoritma DBSCAN dengan mengadopsi Algoritma DMDBSCAN untuk mendapatkan nilai Eps secara otomatis. DMDBSCAN menerapkan cara kerja dari k-dist plot dalam menemukan nilai parameter Eps dari seluruh kepadatan dalam kumpulan data. Algoritma DMDBSCAN secara otomatis membuat nilai Eps. Pilihan nilai Eps diperoleh dengan mencari perubahan kemiringan (slope) garis maksimum pada 3 jarak dari tetangga paling dekat pada distribusi data. Namun, prosedur tersebut sangat memiliki pengaruh terhadap perubahan kemiringan (slope) garis yang sangat jauh. Kamudian, untuk nilai $\mathrm{k}$ pada fungsi algoritmanya memiliki nilai tetap pada $\mathrm{k}$ bernilai 3. Faktor tersebut menjadikan kegunaan algoritma tidak bekerja untuk nilai k lainnya dan kurang efisien untuk mencari nilai Eps yang optimal.

Penelitian ini melakukan modifikasi fungsi pencarian nilai Eps optimal secara otomatis pada Algoritma DMDBSCAN. Kemudian, nilai parameter digunakan dalam pengelompokan data titik gempa di Indonesia tahun 2014-2020. Modifikasi Algoritma DMDBSCAN diharapkan dapat menjadi acuan pencarian parameter Eps pada algoritma DBSCAN yang lebih tepat dan mengetahui penyebaran titik gempa bumi di Indonesia.

\section{METODE}

\section{Data Penelitian}

Data yang diolah dalam penelitian ini adalah data gempa bumi di Indonesia yang diperoleh melalui situs resmi http://repogempa.bmkg.go.id, dengan dataset berjumlah 47.908 dari tahun 2014 sampai 2020. Data berupa: latitude (Lat), longitude (Lon), tanggal (Date), waktu (Time), kedalaman (Dep), magnitudo (M) dan wilayah (Region).

\section{Prapemrosesan Data}

Pada tahap ini dilakukan pemilihan variabel dan koordinat titik gempa. Variabel tersebut adalah variabel magnitudo, longitude dan latitude. Kemudian, mempartisi data setiap tahunnya dari tahun 2014 hingga 2020.

\section{Penentuan Nilai Eps Optimal}

Pada tahap ini, modifikasi Algoritma DBSCAN dilakukan dengan ide DMDBSCAN agar mendapatkan nilai Eps optimal. DMDBSCAN menerapkan ide k-dist plot guna mencari nilai Eps yang cocok dengan posisi kepadataan data. Prosedur dalam mencari nilai Eps dalam setiap posisi kepadatan yang sesuai meliputi : 1) Menghitung k-dist pada setiap titik dan membagi k-dist plot, 2) Jumlah kepadatan diberikan oleh k-dist plot secara intuitif, dan 3) Memilih parameter Eps untuk setiap kepadatan secara otomatis (Elbatta, 2012). Susunan algoritma penentuan nilai parameter Eps terdapat dalam Gambar 1. 


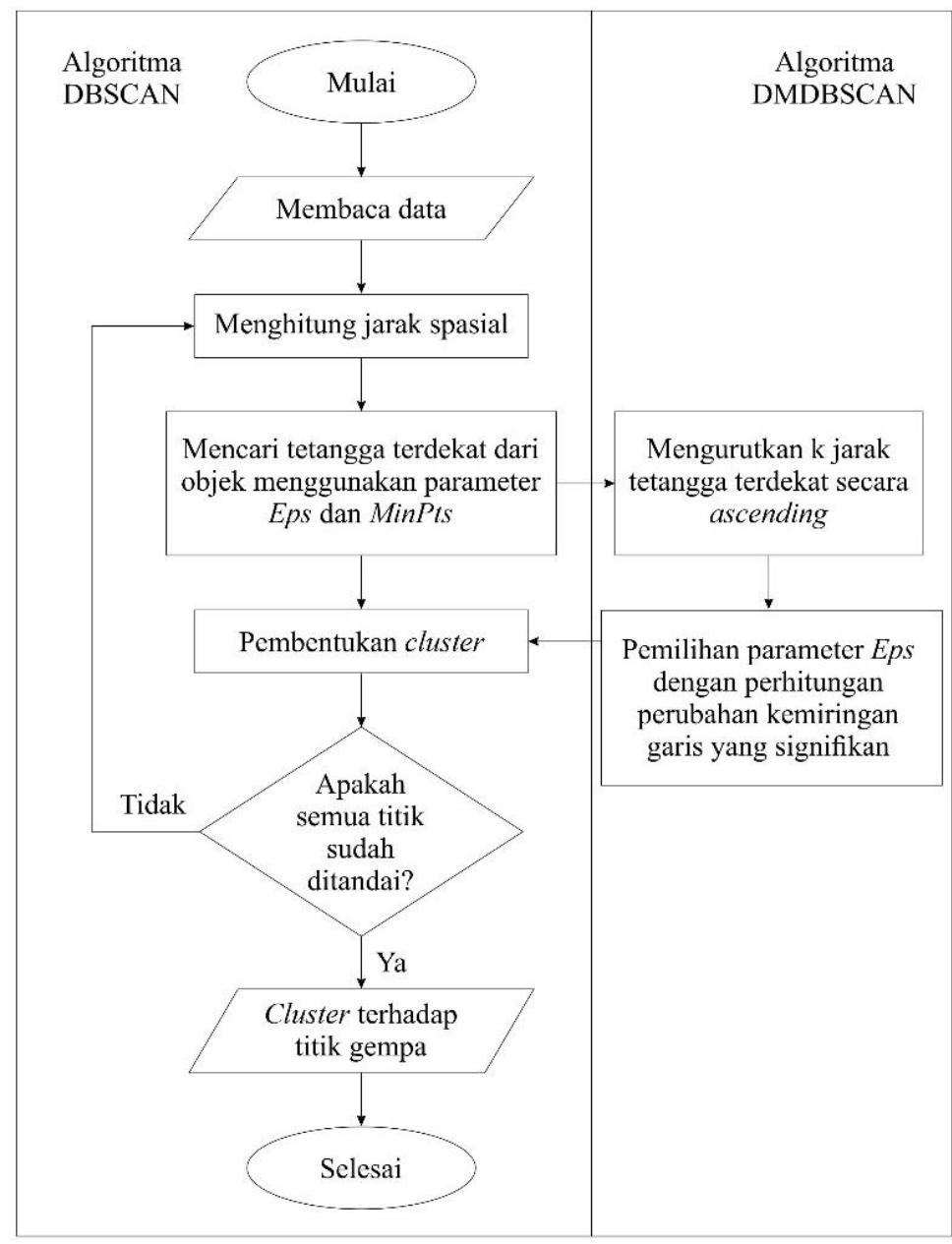

Gambar 1 Diagram alir algoritma penelitian

Algoritma DMDBSCAN dimulai dengan menambahkan tahapan-tahapan dalam Algoritma DBSCAN. Algoritma ini memulainya dengan menghitung euclidean distance dengan fungsi dist untuk setiap pasangan variabel latitude dan longitude. Kemudian, mengganti nilai dist menjadi matriks lengkap. Selanjutnya, menghitung spatial distance dengan perhitungan euclidean distance. Letak perubahan yang dilakukan dalam penelitian ini terdapat pada penemuan nilai parameter Eps optimal dengan menghitung jarak k dari tetangga paling dekat, lalu penghitung perubahan kemiringan (slope) garis yang bernilai diantara $10 \%-20 \%$ serta mencari nilai terkecil yang berada dalam rentang yang disebutkan sebelumnya. Maka dari itu, nantinya akan ditemukan nilai parameter Eps optimal yang dijadikan sebagai nilai masukan parameter Algoritma DBSCAN.

\section{Pengelompokkan Data Titik Gempa Menggunakan Nilai Eps Optimal}

Nilai parameter Eps secara optimal dan otomatis dihasilkan dari Algoritma DMDBSCAN modifikasi. Kedua nilai parameter (Eps dan MinPts) dipakai guna mempartisi data titik gempa di Indonesia menjadi beberapa kelompok pada tahun 2014-2020 dengan manitudo berkekuatan diatas 5,5 setiap tahunnya.

Terdapat beberapa kategori gempa bumi dengan nilai dan tingkat magnitudo yang memiliki nilai berbeda pada skala gempa yang dipakai oleh BMKG. Magnitudo 8 atau lebih, masuk dalam kelompok gempa yang memiliki kekuatan hebat. Magnitudo sebesar ini bisa meruntuhkan komunitas di sekitar titik inti gempa. Gempa dengan magnitudo 7-7,9 termasuk pada kelas gempa besar yang berakibat kerusakan yang serius. Kemudian, kekuatan gempa yang memiliki skala gempa berkisar antara 6,1-6,9 masuk pada kelas gempa bumi yang kuat. Gempa bumi yang memiliki magnitudo sebesar ini bisa mengakibatkan banyak sekali perubahan struktur bumi di wilayah yang memiliki penduduk yang padat. Kekuatan gempa 5,5-6,0 termasuk pada kalas gempa sedang. Kekuatan magnitudo sebesar ini bisa mengakibatkan kerusakan yang ringan seperti pada infrastruktur lainnya dan bangunan. Gempa dengan kekuatan 2,5-5,4 masuk dalam kelompok gempa yang ringan. Kekuatan magnitudo sebesar ini dapat dirasa oleh penduduk, namun hanya mengakibatkan kerusakan yang kecil. Kelas gempa dengan skala gempa paling rendah adalah dibawah 2,5. Kekuatan gempa sebesar ini umumnya tak terasa, namun bisa dicatat menggunakan alat bantu seismograf (detikcom, 2021). Penelitian ini 
melakukan pengelompokkan terhadap data gempa menggunakan magnitudo diatas 5,5 karena sudah dapat mengakibatkan kerusakan pada bangunan dan infrastruktur lainnya.

Kemudian, proses clustering dilakukan menggunakan kedua parameter, ialah parameter Eps dan parameter MinPts. Nilai Eps dipakai dalam penentuan jarak maksimal/radius secara otomatis titik objek dalam cluster dari titik inti cluster. Nilai MinPts dalam Algoritma DMDBSCAN yang diperoleh dari nilai k dipakai guna memberi batas terhadap jumlah titik-titik yang termasuk dalam objek cluster pada jarak maksimal Eps (Ester, Kriegel, Sander, \& Xu, 1996). Kemudian, setelah nilai Eps dan MinPts diperoleh, tahapan selanjutnya diterapkan langkah-langkah berikut: 1) melakukan pengelompokkan titik yang tersisa dengan cara menghubungkan seluruh titik inti (core) dengan jarak yang lebih kecil dari Eps, 2) membentuk masing-masing kelompok dari titik core yang saling terhubung satu sama lain menjadi cluster yang berbeda, dan 3) menentukan setiap titik batas pada satu clustering paling dekat dengan clusternya (Ester, Kriegel, Sander, \& $\mathrm{Xu}, 1996)$. Tahapan clustering yang terdapat pada penelitian ini menambahkan perhitungan nilai parameter Eps pada Algoritma DBSCAN sehingga memberikan objek cluster dengan parameter yang dipakai.

\section{Analisis Cluster}

Dalam tahapan analisis, analisis pengelompokkan serta implementasi algoritma DMDBSCAN dijalankan dengan mengelompokkan data titik gempa menggunakan R. Hasil yang didapatkan dalam analisis ini meliputi perbedaan nilai parameter Eps yang dihasilkan Algoritma DMDBSCAN sebelum dengan sesudah perubahan. Evaluasi pengelompokan dijalankan pada tahap ini menggunakan lima indeks validasi: indeks Silhoutte (SI), Dunn index, DB index, BetaCV, dan Calinski Harabasz index.

a. Silhoutte Index (SI)

Indeks SI yang memiliki nilai mendekati 1 mempunyai arti bahwa objek semakin cocok dalam cluster. Indeks SI yang memiliki nilai negatif menandakan objek tersebut tidak cocok berada dalam cluster. Indeks SI yang memiliki nilai 0 (atau mendekati nol) menandakan objek tersebut terletak pada batas antara dua cluster (Tan, Steinbach, \& Kumar, 2006). Nilai SI dapat dicari dengan Persamaan (1).

$S I=\frac{1}{k} \sum_{j=1}^{k} S I_{j}$

dimana:

$\mathrm{SI}=$ Silhoutte Index global

$k=$ jumlah cluster.

$S I_{j}=$ Silhoutte Index cluster $\mathrm{ke}-\mathrm{j}$

b. Indeks Dunn

Nilai indeks Dunn berada pada rentang 0 hingga tidak terhingga. Nilai indeks Dunn yang tinggi menunjukkan efek clustering yang baik. (Rendon, Abundez, Arizmendi, \& Quiroz, 2011). Formulasi nilai Dunn dapat dihitung menggunakan Persamaan (2).

Dunn $=\min _{1 \leq i \leq c}\left\{\min \left\{\frac{d\left(c_{i}, c_{j}\right)}{\max _{1 \leq k \leq c}\left(d\left(x_{k}\right)\right)}\right\}\right\}$

dimana:

Dunn = Indeks Dunn

$c=$ jumlah cluster

$d\left(c_{i}, c_{j}\right)=$ distance antara objek pada cluster ke-i dan objek pada cluster ke-j

$d\left(x_{k}\right)=$ distance antar objek pada cluster ke-k

c. Indeks Davies-Bouldin (DB)

Indeks DB digunakan guna mengidentifikasi hasil cluster dengan kekompakan dan keterpisahan yang baik. Nilai indeks DB yang rendah dapat diartikan bahwa semakin baik clustering yang dihasilkan (Rendon, Abundez, Arizmendi, \& Quiroz, 2011). Nilai Davies-Bouldin dapat dihitung menggunakan Persamaan (3).

$D B=\frac{1}{C} \sum_{i=1}^{c} \max _{i \neq j}\left\{\frac{d\left(x_{i}\right)+d\left(x_{j}\right)}{d\left(c_{i}, c_{j}\right)}\right\}$.

dimana:

$D B=$ Indeks Davies-Bouldin 
$c=$ jumlah cluster

$i$ dan $j=$ label cluster

$d\left(x_{i}\right)$ dan $d\left(x_{j}\right)=$ jarak antara objek pada klaster ke-i dan $\mathrm{j}$ terhadap pusat cluster

$d\left(c_{i}, c_{j}\right)=$ jarak antara pusat cluster ke-i dan $\mathrm{j}$

d. BetaCV

BetaCV digunakan untuk mengukur baik-tidaknya suatu cluster berdasarkan hubungan antara jarak rata-rata pada suatu cluster dan jarak rata-rata antar cluster. Nilai BetaCV yang semakin rendah memiliki arti bahwa semakin baik efek clusteringnya (University of Illinois, 2020). Nilai BetaCV dapat dihitung menggunakan Persamaan (4).

BetaCV $=\frac{W_{\text {in }} / N_{\text {in }}}{W_{\text {out }} / N_{\text {out }}}$

dimana:

BetaCV = Indeks BetaCV

$W_{\text {in }}=$ jumlah seluruh jarak antara titik pada cluster

$N_{\text {in }}=$ jumlah titik berpasangan pada cluster

$W_{\text {out }}=$ jumlah seluruh jarak antar titik dalam cluster berbeda

$N_{\text {out }}=$ jumlah titik berpasangan dalam cluster berbeda

e. Indeks Calinski-Harabasz $(\mathrm{CH})$

Jumlah cluster terbaik ditunjukkan dari nilai indeks Calinski-Harabasz tertinggi (Baarsch, 2012).

Nilai $\mathrm{CH}$ dapat dihitung menggunakan Persamaan (5).

$C H=\frac{\operatorname{trace}(S S B)}{\operatorname{trace}(S S W)} \times \frac{N-k}{k-1}$

dimana:

$\mathrm{CH}=$ Indeks Calinski Harabasz

Sum of Square between cluster $(S S B)=$ separation

Sum of Square within - cluster $(S S W)=$ compactness

$N=$ jumlah data

$k=$ jumlah cluster

\section{HASIL DAN PEMBAHASAN}

\section{Mendeskripsikan Data Gempa Bumi di Indonesia Tahun 2014-2020.}

Dalam tahapan ini, diterapkan descriptive analysis terkait dengan karakteristik dan pola yang ada pada data gempa di Indonesia mulai dari tahun 2014 sampai dengan tahun 2020. Total jumlah titik gempa yang disediakan dalam situs resmi BMKG pada tiap tahunnya disajikan dalam Tabel 1. Kemudian, analisis deskriptif juga dilakukan terhadap dua karakteristik gempa bumi, ialah variabel magnitudo (M) serta variabel kedalaman (Dep). Analisis tersebut disajikan pada Tabel 2 dan Tabel 3.

Tabel 1. Jumlah observasi dan daerah titik gempa terbanyak pada data gempa bumi tahun 2014-2020

\begin{tabular}{cccc}
\hline Tahun & Jumlah Observasi & Daerah Titik Gempa Terbanyak & Jumlah Titik \\
\hline 2014 & 2427 & Java, Indonesia & 277 \\
2015 & 4210 & Banda Sea & 447 \\
2016 & 3853 & Minahassa Peninsula, Sulawesi & 426 \\
2017 & 5302 & Sulawesi, Indonesia & 576 \\
2018 & 12018 & Sumbawa Region & 2749 \\
2019 & 11787 & Sulawesi, Indonesia & 1449 \\
2020 & 8310 & Sulawesi, Indonesia & 837 \\
\hline
\end{tabular}

Tabel 1 memperlihatkan total observasi gempa bumi yang terjadi dan wilayah yang memiliki titik gempa paling banyak dalam data gempa pada tahun 2014-2020 setiap tahunnya. Terlihat bahwa kejadian terbanyak terjadi dalam tahun 2018 dengan total jumlah titik gempa bumi yang terjadi adalah sebanyak 12018 dan paling banyak terjadi di daerah Sumbawa dengan jumlah titik sebanyak 2749. 
Tabel 2. Analisis deskriptif variabel magnitudo

\begin{tabular}{ccccc}
\hline Tahun & Min & Rerata & Max & Daerah Magnitudo Tinggi \\
\hline 2014 & 1.5 & 3.798 & 6.3 & Northern Molucca Sea \\
2015 & 3 & 3.971 & 6.9 & Irian Jaya, Indonesia \\
2016 & 3 & 3.918 & 7.7 & Southwest of Sumatra \\
2017 & 3 & 3.876 & 7.2 & Celebes Sea \\
2018 & 1.1 & 3.414 & 7.5 & Minahassa Peninsula, Sulawesi \\
2019 & 1.5 & 3.477 & 7.3 & Banda Sea \\
2020 & 1.1 & 3.487 & 7.1 & Southwest of Sumatra \\
\hline
\end{tabular}

Tabel 2 memperlihatkan descriptive analysis magnitudo serta wilayah yang mempunyai peristiwa gempa bumi dengan kekuatan magnitudo paling tinggi dalam data gempa bumi tahun 2014 sampai dengan tahun 2020 setiap tahunnya. Terlihat bahwa gempa bumi dengan magnitudo paling tinggi terjadi pada tahun 2016 di daerah Southwest of Sumatra dengan kekuatan gempa bumi sebesar 7.7.

Tabel 3. Descriptive analysis variabel depth

\begin{tabular}{ccccc}
\hline Tahun & Min & Rerata & Max & Daerah Depth Rendah \\
\hline 2014 & 5 & 54.98 & 732 & Northern Sumatra \\
2015 & 2 & 60.8 & 692 & Sulawesi, Indonesia \\
2016 & 10 & 63.14 & 750 & Halmahera, Indonesia \\
2017 & 3 & 58.53 & 750 & Southern Sumatra \\
2018 & 5 & 41.03 & 750 & Minahassa Peninsula, Sulawesi \\
2019 & 3 & 38.76 & 750 & Seram, Indonesia \\
2020 & 5 & 48.43 & 750 & Southwest of Sumatra \\
\hline
\end{tabular}

Tabel 3 memperlihatkan descriptive analysis variabel kedalaman serta wilayah yang mempunyai peristiwa gempa bumi dengan depth/kedalaman terendah dalam data gempa tahun 2014 sampai dengan tahhun 2020 setiap tahunnya. Terlihat bahwa gempa dengan kedalaman paling rendah terjadi pada tahun 2015 di wilayah Sulawesi dengan jarak kedalaman sejauh 2KM.

\section{Penentuan Nilai Eps Optimal}

Dalam tahapan ini, modifikasi Algoritma DMDBSCAN dilakukan. Algoritma/metode sebelum ini telah menambahkan metode penentuan nilai parameter Eps dengan k yang memiliki nilai tetap pada k bernilai 3 dalam Algoritma DBSCAN dan penentuan nilai parameter Eps diterapkan dengan cara menemukan perubahan kemiringan garis maksimum pada kurva.

DMDBSCAN setelah modifikasi menambahkan penentuan nilai parameter Eps dengan menjadikan nilai k menjadi nilai masukan. Selanjutnya, penentuan nilai parameter Eps optimal dalam Algoritma DMDBSCAN setelag modifikasi diterapkan menggunakan cara menemukan perubahan (slope) pada rentang antara 10\%$20 \%$ serta memilih titik terendah apabila ditemukan lebih dari satu nilai dalam rentang yang telah disebutkan. Pseudocode Algoritma DMDBSCAN setelah modifikasi disajikan dalam Gambar 2.

\begin{tabular}{|c|c|}
\hline \multicolumn{2}{|c|}{$\begin{array}{l}\text { Algoritma } 1 \text { Pseudocode teknik yang diusulkan DMDBSCAN guna mencari nilai parameter Eps yang } \\
\text { cocok untuk setiap kepadatan pada distribusi data. }\end{array}$} \\
\hline Purpose & Untuk mencari nilai Eps yang sesuai \\
\hline Input & Distribusi data berukuran $\mathrm{n}$ \\
\hline Output & Parameter Eps untuk setiap kepadatan bervariasi \\
\hline Procedure & $\begin{array}{ll}1 & \text { for } \mathrm{i} \\
2 & \text { for } \mathrm{j}=1 \text { to } \mathrm{n} \\
3 & \mathrm{~d}(\mathrm{i}, \mathrm{j}) \leftarrow \text { temukan jarak (xi, } \mathrm{xj}) \\
4 & \text { temukan nilai minimum jarak ke } \mathrm{k} \text { titik terdekat } \\
5 & \text { end for } \\
6 & \text { end for } \\
7 & \text { urutkan jarak naik dan plot untuk menemukan setiap nilai } \\
8 & \mathrm{~s}(\mathrm{i}, \mathrm{j}) \leftarrow \text { temukan nilai slope } \text { antara } 10 \% \text { hingga } 20 \% \\
9 & \text { temukan nilai minimum pada rentang slope }\end{array}$ \\
\hline
\end{tabular}

Gambar 2 Pseudocode Algoritma DMDBSCAN setelah modifikasi

Algoritma memulai tahapannya dengan perhitungan euclidean distance dalam tiap pasangan atribut longitude serta latitude menggunakan kegunaan dist. Kemudian adalah menjadikan data dist menjadi matriks lengkap dengan memakai kegunaan as.matrix. Kegunaan as.matrix dipakai dikarenakan dist yang dihasilkan 
berbentuk upper triangular matrix. Oleh karena itu butuh adanya normalisasi ke matriks lengkap. Perlakuan normalisasi dipakai guna mempermudah penentuan $\mathrm{k}$ tetangga terdekat dalam tiap baris perhitungan jarak. Gambaran distance matrix berukuran $n \times n$ disajikan dalam Gambar 3 dengan menerapkan Persamaan (6).

$$
\left[\begin{array}{ccccc}
0 & & & & \\
d(2,1) & 0 & & & \\
d(3,1) & d(3,2) & 0 & & \\
\vdots & \vdots & \vdots & & \\
d(n, 1) & d(n, 2) & \cdots & \cdots & 0
\end{array}\right]
$$

Gambar 3 Distance matrix berukuran nxn

Dalam Gambar 3, $d(i, j)$ merupakan distance antara objek i dan j. Biasanya, $d(i, j)$ diartikan sebagai nilai yang bertanda postif yang mendekati 0 ketika objek i dan $\mathrm{j}$ sangat dekat atau mirip satu sama lain dan menjadi lebih besar ketika 2 objek tersebut berbeda. Gambar 3 memperlihatkan bentuk matriks segitiga atas karena $d(i, j)=d(j, i)$ dan $d(i, i)=0$. Jarak euclidean adalah perhitungan jarak yang banyak digunakan karena jarak tersebut sensitif terhadap outlier. Formula jarak euclidean ditunjukkan dalam Persamaan (6). Variabel i dan j pada Persamaan (6) merupakan objek 2 dimensi (Han, Kamber, \& Pei, 2012).

$d(i, j)=\sqrt{\left(x_{\text {long }_{i}}-x_{\text {long }_{j}}\right)^{2}+\left(x_{\text {lat }_{i}}-x_{\text {lat }_{j}}\right)^{2}}$

Setelah memperhitungkan matriks dan jarak, kemudian dilakukan permulaan dalam menghitung total jumlah baris dalam objek memakai kegunaan nrow. Kemudian, diterapkan penentuan 3 tetangga paling dekat dari masing-masing baris distance matrix sebagai perlakuan diurutkannya dengan urutan menaik bagi setiap hasil jarak paling dekat dalam tetangga. Urutan yang dihasilkan pada masing-masing baris tetangga paling dekat digambarkan dalam sebuah plot dimana objek disimbolkan dengan sumbu $\mathrm{x}$ dan jarak $\mathrm{k}$ tetangga terdekat disimbolkan dengan sumbu y. Setelah plot dibentuk secara menaik, kemudian perhitungan selisih kemiringan garis dilakukan guna menemukan nilai parameter Eps (Gonkar \& Sawant, 2013). Objek yang memiliki perubahan kemiringan yang signifikan akan dijadikan sebagai nilai parameter Eps yang optimal (Elbatta, 2012). Dalam Algoritma DMDBSCAN pada penentuan nilai parameter Eps optimal diterapkan untuk setiap level kepadatan yang mana nantinya akan menemukan parameter Eps sesuai tingkat kepadatannya (Elbatta, 2012). Penemuan parameter Eps sesuai dengan tingkat kepadatannya menggunakan perhitungan selisih kemiringan garis dengan threshold antara $10 \%$ sampai $20 \%$. Selisih kemiringan garis (slope) yang mempunyai bernilai dalam rentang 10\% sampai 20\% adalah nilai parameter Eps yang optimal (Gonkar \& Sawant, 2013).

Algoritma DMDBSCAN pada penelitian ini menggunakan single level density pada penentuan nilai parameter Eps optimal dimana nantinya hanya memberikan satu nilai Eps. Perhitungan parameter Eps pada single level density yaitu dengan mencari slope antar objek memakai persamaan (y2-y1)/(x2-x1) dengan nilai threshold berkisar 10\% sampai 20\%. Jika terdapat nilai Eps lebih dari satu, maka akan dipilih parameter Eps optimal terkecil. Nilai inilah yang dijadikan sebagai parameter Eps.

\section{Perbandingan Hasil Algoritma DMDBSCAN Sebelum dan Setelah Modifikasi}

Proses analisis dilakukan berdasarkan clustering analysis serta penerapan Algoritma DMDBSCAN terhadap klasterisasi titik gempa bumi pada tahun 2020 yang memiliki kekuatan gempa $\geqslant 5,5$. Hasil analisis meliputi perbedaan serta perbandingan nilai parameter Eps dengan Algoritma DMDBSCAN sebelum dan setelah perubahan/modifikasi. Clustering analysis yang diterapkan memberikan hasil perbandingan nilai parameter Eps dengan Algoritma DMDBSCAN sebelum dan setelah perubahan seperti dalam Tabel 4.

Tabel 4. Perbandingan nilai parameter Eps Algoritma DMDBSCAN sebelum dan setelah perubahan/modifikasi

\begin{tabular}{ccc}
\hline \multirow{2}{*}{$\mathrm{K}$} & \multicolumn{3}{c}{ Nilai Epsilon yang Dihasilkan } \\
\cline { 2 - 3 } & Sebelum Modifikasi & Setelah Modifikasi \\
\hline 3 & 4.753210 & 0.571849 \\
5 & 8.121498 & 0.717057 \\
$\mathbf{6}$ & 7.517217 & 0.983589 \\
7 & $\mathbf{8 . 9 5 5 8 6 4}$ & $\mathbf{8 . 9 5 5 8 6 4}$ \\
\hline
\end{tabular}

Nilai parameter yang dihasilkan dari simulasi parameter pada Tabel 4 memiliki arti bahwa parameter Eps optimal menggunakan Algoritma sebelum dan setelah perubahan/modifikasi memperlihatkan perbedaan yang cukup jauh, kecuali pada saat k=6. Nilai Eps optimal pada saat k=6, keduanya menghasilkan nilai parameter 
Eps optimal yang bernilai 8.955864. Untuk mengetahui tingkat kebaikan jumlah kelompok yang diberikan oleh masing-masing pasangan parameter, akan dihitung lima validation index, diantaranya adalah nilai Indeks Silhoutte (SI), Dunn index, DB index, BetaCV, serta Calinski-Harabasz (CH) index.

Tabel 5. Perbandingan nilai indeks validasi Algortima DMDBSCAN sebelum dan setelah modifikasi tahun 2020

\begin{tabular}{|c|c|c|c|}
\hline \multirow{2}{*}{$\mathrm{k}$} & \multirow{2}{*}{ Indeks Validasi } & \multicolumn{2}{|c|}{ Nilai Indeks Validasi dari Epsilon yang Dihasilkan } \\
\hline & & Eps (sebelum modifikasi) & Eps (setelah modifikasi) \\
\hline \multirow{5}{*}{3} & SI & 0.32 & 0.65 \\
\hline & Dunn & 0.2233 & 1.4287 \\
\hline & $D B$ & 0.4752 & 0.1705 \\
\hline & BetaCV & 0.2958 & 0.0061 \\
\hline & $\mathrm{CH}$ & 151 & 120498 \\
\hline \multirow{5}{*}{4} & $S I$ & - & 0.49 \\
\hline & Dunn & Inf & 5.3611 \\
\hline & $D B$ & $\mathrm{NaN}$ & 0.1025 \\
\hline & BetaCV & Inf & 0.0035 \\
\hline & $\mathrm{CH}$ & $\mathrm{NaN}$ & 386173 \\
\hline \multirow{5}{*}{5} & SI & 0.53 & 0.56 \\
\hline & Dunn & Inf & 4.0551 \\
\hline & $D B$ & Nan & 0.1197 \\
\hline & BetaCV & 33.14 & 0.0086 \\
\hline & $\mathrm{CH}$ & Inf & 61115 \\
\hline \multirow{5}{*}{6} & $S I$ & 0.14 & 0.14 \\
\hline & Dunn & Inf & Inf \\
\hline & $D B$ & Nan & $\mathrm{NaN}$ \\
\hline & BetaCV & 97.55 & 97.55 \\
\hline & $\mathrm{CH}$ & Inf & Inf \\
\hline \multirow{5}{*}{7} & $S I$ & 0.14 & 0.35 \\
\hline & Dunn & Inf & 0.2233 \\
\hline & $D B$ & $\mathrm{NaN}$ & 0.4940 \\
\hline & BetaCV & 97.55 & $\mathbf{0 . 3 1 3 4}$ \\
\hline & $\mathrm{CH}$ & Inf & 148 \\
\hline
\end{tabular}

Dapat dilihat pada Tabel 5 yang menunjukkan hasil penilaian/evaluasi klaster menggunakan kelima validation index. Algoritma DMDBSCAN sebelum perubahan/modifikasi menunnjukkan angka yang kurang baik. Apabila setiap indeks dibandingkan, Algoritma setelah perubahan/modifikasi memberikan nilai Indeks Silhoutte (SI), serta Calinski-Harabasz (CH) index yang lebih tinggi, dimana indeks-indeks tersebut mempunyai makna, yaitu kelompok yang baik ditandai dengan semakin tingginya nilai indeks-indeks tersebut. Sedangkan untuk nilai DB index serta BetaCV, Algoritma setelah perubahan/modifikasi memberikan nilai yang lebih rendah, dimana indeks-indeks tersebut mempunyai makna, yaitu kelompok yang baik ditandai dengan semakin rendahnya nilai indeks-indeks tersebut.

\section{Implementasi Algoritma DMDBSCAN Modifikasi Pada Data Gempa Bumi Indonesia}

Partisi diterapkan terhadap data titik gempa pada daerah Indonesia setiap tahunnya dengan magnitudo berkekuatan $\geqslant 5,5$. Untuk memberikan contoh, dipakai data titik gempa bumi pada tahun 2020. Distribusi data seperti yang tampak dalam Gambar 4.

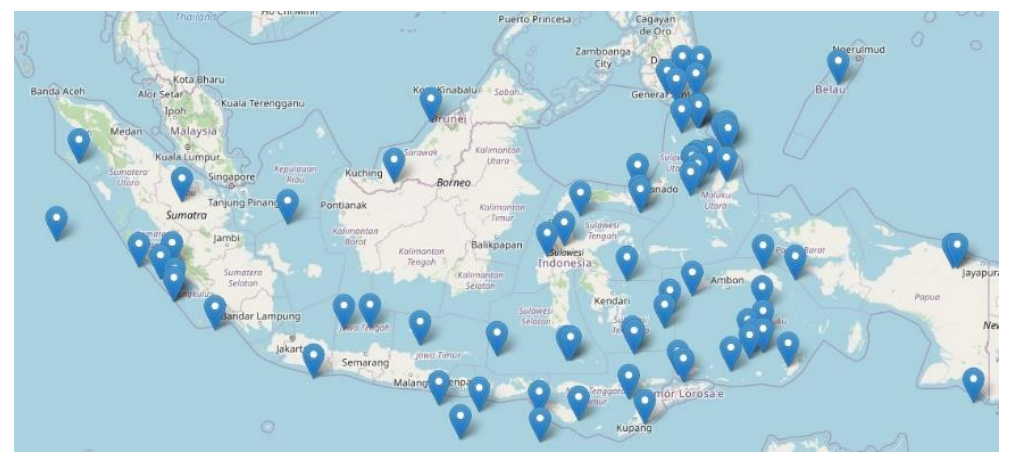

Gambar 4 Distribusi titik gempa bumi tahun 2020 dengan $M \geqslant 5,5$ 
Seusai partisi terhadap waktu terjadinya gempa bumi (1 Januari 2020 - 31 Desember 2020) dilakukan, penentuan titik gempa diterapkan berdasarkan besarnya kekuatan gempa serta ditentukan objek titik gempa yang mempunyai kekuatan $\geqslant 5,5$. Setelah pemilihan objek titik gempa pada tahun 2020 diterapkan, prosedur pemisahan terhadap data kekuatan gempa dan waktu memberikan objek titik gempa sejumlah 76 titik. Distribusi data dengan jumlah 76 titik tersebut seperti yang tampak pada Gambar 4.

Tabel 6. Perbandingan nilai indeks validasi Algoritma DMDBSCAN setelah modifikasi saat $\mathrm{k}$ bernilai 3 - 7 pada data gempa bumi tahun 2020

\begin{tabular}{ccccccc}
\hline \multirow{2}{*}{$\mathrm{k}$} & \multirow{2}{*}{ Eps } & SI & Dunn & DB & BetaCV & CH \\
\cline { 3 - 6 } & & 0.65 & 1.4287 & 0.1705 & 0.0061 & 120703 \\
3 & 0.5718 & 0.49 & $\mathbf{5 . 3 6 1 1}$ & $\mathbf{0 . 1 0 2 5}$ & $\mathbf{0 . 0 0 3 5}$ & $\mathbf{3 8 6 8 3 0}$ \\
4 & 0.7170 & 0.56 & 4.0551 & 0.1197 & 0.0086 & 61219 \\
5 & 0.9835 & 0.14 & Inf & NA & 97.52 & Inf \\
6 & 9.0118 & 0.35 & 0.2271 & 0.4975 & 0.3131 & 148 \\
7 & 6.1746 & & & & & \\
\hline
\end{tabular}

Tabel 6 adalah perbedaan hasil validation index dari kelima nilai k dengan pasangan parameter Eps optimalnya, dimana kemudian nilai k dengan pasangan parameter Eps optimalnya dengan index terbaik digunakan sebagai nilai masukan parameter Algoritma DBSCAN dalam DMDBSCAN pada teknik clustering atau pengelompokkan. Dapat diketahui bahwa pada tahun 2020, pasangan nilai dengan index paling baik diperlihatkan dengan k yang memiliki nilai 4 serta Eps optimal yang memiliki nilai 0.7170. Kemudian, tahapan clustering dilakukan menggunakan nilai parameter MinPts $=4$ serta Eps $=0.7170$. Perbandingan nilai indeks validasi yang terdapat pada Tabel 6 merupakan contoh perbandingan menggunakan data titik gempa di Indonesia tahun 2020. Simulasi ini diterapkan juga kepada data gempa bumi pada tahun 2014-2020.

Teknik klasterisasi berhasil dilakukan pada data gempa tahun 2020 menggunakan DMDBSCAN modifikasi dan menghasilkan nilai MinPts $=4$ dan Eps $=0.7170$. Parameter ini dipakai dalam prosedur klasterisasi dan hasilnya adalah terbentuk dua klaster dengan titik noise sebanyak 66.

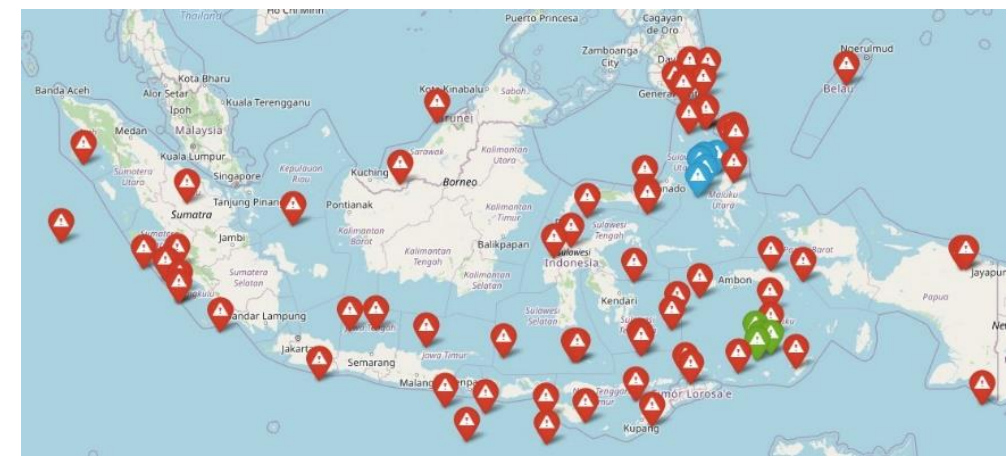

Gambar 5 Distribusi klaster titik gempa bumi tahun 2020

Gambar visualisasi daerah kelompok objek gempa di Indonesia pada tahun 2020 yang memiliki kekuatan gempa $\geq 5.5$ diperlihatkan dalam Gambar 5. Titik gempa bumi yang berada pada daerah cluster 1 ditunjukkan oleh icon berwarna hijau. Titik gempa bumi yang berada pada daerah cluster 2 ditunjukkan oleh icon berwarna biru. Titik gempa bumi yang terdeteksi sebagai noise atau outlier ditunjukkan oleh icon berwarna merah. Hal ini juga diterapkan pada data gempa tahun 2014-2020. Daerah kerawanan gempa bumi yang dihasilkan tersaji dalam Tabel 7.

Tabel 7. Daerah rawan gempa bumi tahun 2014-2020

\begin{tabular}{ccclc}
\hline Tahun & Jumlah Cluster & Jumlah Noise & Daerah Rawan Gempa Bumi & Jumlah Titik Gempa \\
\hline 2014 & 2 & 6 & Minahassa Peninsula, Sulawesi & 2 \\
2015 & 2 & 37 & Banda Sea & 4 \\
2016 & 2 & 37 & Sumbawa Region, Indonesia & 2 \\
2017 & 2 & 20 & Halmahera, Indonesia & 2 \\
2018 & 2 & 73 & Sumba Region, Indonesia & 4 \\
2019 & 2 & 72 & Northern Molucca Sea & 4 \\
2020 & 2 & 66 & Banda Sea & 4 \\
\hline
\end{tabular}

Berdasarkan Tabel 7, terlihat bahwa daerah Banda Sea muncul beberapa kali pada daerah rawan gempa bumi, ialah pada tahun 2015 dan 2020. Hal ini dapat menjadi perhatian untuk masyarakat setempat. 


\section{KESIMPULAN}

Hasil analisis deskriptif data gempa bumi di Indonesia pada tahun 2014-2020 bisa diketahui untuk wilayah yang memiliki total jumlah titik gempa paling banyak dan wilayah dengan gempa yang mempunyai magnitudo paling tinggi serta kedalaman terdangkal. Selain itu, perubahan/modifikasi yang dilakukan terhadap Algoritma DMDBSCAN dalam menghasilkan nilai Eps optimal berhasil dilakukan serta memberikan nilai yang lebih baik dan bisa mempertimbangkan nilai masukan $\mathrm{k}$ pada pembentukan $k$-dist plot. Penerapan Algoritma DMDBSCAN modifikasi berjalan dengan baik untuk mendapatkan daerah kerawanan gempa.

Dilihat dari hasil yang diperoleh, terdapat beberapa hal yang masih bisa dilakukan untuk meningkatkan performa dari penentuan nilai Eps optimal seperti melakukan studi lanjutan dalam mencari nilai Eps optimal karena penelitian ini hanya memodifikasi nilai kemiringan garis berkisar 10\% sampai 20\%, serta hal ini baru berhasil diterapkan pada data gempa bumi di Indonesia. Penerapan DMDBSCAN pada penentuan nilai Eps juga dapat dilakukan untuk kepadatan yang beragam. Selain itu, descriptive analysis yang dihasilkan dapat dihubungkan dengan analisis lainnya seperti ilmu lempengan bumi serta geologi.

\section{DAFTAR PUSTAKA}

Amri, M. R., Yulianti, G., Yunus, R., Wiguna, S., Adi, A. W., Ichwana, A. N., . . Septian, R. T. (2016). RBI: Risiko Bencana Indonesia. Jakarta: BNPB.

Baarsch, J. C. (2012). Investigation of Internal Validity Measures for K-Means Clustering. Lecture Notes in Engineering and Computer Science. 2195., 471-476.

detikcom, T. (2021, January 25). Pengertian Magnitudo, SKALA Gempa Yang Kini Dipakai BMKG. Diambil kembali dari detiknews: https://news.detik.com/berita/d-5348381/pengertian-magnitudo-skalagempa-yang-kini-dipakai-bmkg

Elbatta, M. (2012). An improvement for DBSCAN algorithm for best results in varied densities [disertasi]. Gaza: Islamic University of Gaza.

Ester, M., Kriegel, H., Sander, J., \& Xu, X. (1996). A density-based algorithm for discovering clusters in large spatial databases with noise. Proceedings of 2nd International Conference on Knowledge Discovery and Data Mining (KDD-96), 226-231.

Gonkar, M., \& Sawant, K. (2013). AutoEps DBSCAN: DBSCAN with Eps automatic for large dataset. International Journal on Advanced Computer Theory and Engineering, 2(2): 11-16.

Han, J., Kamber, M., \& Pei, J. (2012). Data Mining: Concepts and Techniques. 3rd ed. San Francisco (US): Morgan-Kauffman.

Husein, S. (2016). Proceeding of DRR Action Plan Workshop: Strengthened Indonesian Resilience: Reducing Risk from Disasters.

Rahmah, N., \& Sitanggang, S. I. (2016). Determination of optimal epsilon (eps) value on dbscan algorithm to clustering data on hotspots in sumatra. IOP conference series: earth and environmental science. Vol. 31, No. 1, p. 012012. IOP.

Rendon, E., Abundez, I., Arizmendi, A., \& Quiroz, E. M. (2011). Internal versus external cluster validation indexes. International Journal of computers and communications, 5(1), 27-34.

Sunarjo, S., Gunawan, M. T., \& Pribadi, S. (2012). Gempa Bumi Edisi Populer. Jakarta: Badan Meteorologi Klimatologi dan Geofisika.

Tan, P., Steinbach, M., \& Kumar, V. (2006). Introduction to Data Mining. Boston (US): Pearson Education. 